\title{
TERRORISM IN TURKEY
}

Dr. Atilla YAYLA

\section{INTRODUCTION}

By the time the military intervened in Turkey on 12th of September 1980 , terrorism, whether from right wing or left wing, was claiming the lives of some twenty or more Turkish citizens every day. Altogether more than 5000 people died between 1977 and 1980. Besides ordinary citizens, a number of leading figures had been assasinated including Abdi Ipekçi, journalist and editor of the influential daily newspaper Milliyet and Prof. Dr. Nihat Erim, a former Prime Minister. Those years witnessed the bloody terrorist campaigns conducted by the Marxist-Leninist left pro-Fascist right and Marxist-Leninist Kurdish separatist groups. Also the country was shocked by the explosion of secterian "anonymous" violence in Kahraman Maras in December 1978 which claimed more than 100 lives in a particularly bloody episode. Similar explosions happened in following years in Çorum, Elazığ, Malatya. Additionally some terrorist groups "liberated" several towns in Anatolia and killed those who had different political beliefs or who did not obey them...

Why did Turkey suffer so much from terrorism? Who conducted these bloody terrorist actions? What did they want and what did they do?

In this article I shall try to discuss some characteristics of terrorism in Turkey. In this context I shall first attempt to underline the ideological and strategical views of the terrorist organizations and the predominant terrorists in the first and second waves of terrorism. Then I shall try to give information about the general characteristics of Turkish terrorists. The article will end with some suggestions about the future of terrorism.

\section{I - THE FIRST WAVE OF TERRORISM IN TURKEY $1968-73$}

\section{A - THE ROAD OF TERROR: FROM EXTREMIST STUDENTS TO TERRORISTS}

It is generally accepted that terrorist movements in Turkey started with so-cailed "student movements" in the late 1960s. On 12th June, 
1968, a group of students occupied the Law Faculty of Istanbul University. The occupants proclaimed iheir objectives as; (1) "to struggle against the government", (2) "to resist political power as long as possible", (3) "to eliminate the government. representa"ives at the university" in a declaration published with the signature o: Deniz Gezmiş, the leader of the group. This event was tie starting point of terrorism in Turkey. The name of Deniz Gezmis whe was to becorne one of the most prominent figures in terrorism in the following years was heard for the first time by the Turkish people in connection with this event.

The first generation of leading Turkish terrorists got organised as radical activists within the Federation of Revolutionary Youth Associations (DEV-GENÇ), the main left wing student organization. In general they were extremist university students and some of them, like Mahir Çayan and Sinan Cemgil, vere very promising students. From 1965 to 1969 their political activity aroeared to menifest itself through enthusiastic, idealistic youth groups:. Up to 1969 there were some links between Turkey's only legal Marxist party the Turkish Labour Party and these groups, particularly that of W/ahir Çayan. During this period terror did not appear as a significant item on their itgenda. The Turkish Labour Party's lack of success in the 1969 general elections proved a great disappointment for them an i weakened their belief that a Marxist-Leninist revolution could happen peacefully in Turkey2.

Consequently a year later they moved from peaceful political activities such as the organization of mass demonstrations and rallies against the centre - right government, and NATO, and propogation of socialism among university students and workers, to urban and rural guerilla warfare. In 1969-70, before starting widesspread terrorism, some radical left wing students, including Deniz Gezmi ऊ̧, Hüseyin İnan, travelled to the Palestine Liberation Orgarzation (PLO) camps in Jordan to be trained in guerilla warfare tactics." "lhe year 1971 sitw the development of a new and very surprising phase in the history of the Turkish Republic, with the emergence of three rain terrorist organizations. Organised by extremist students they starled to carry ou: terrorist actions in different parts of Turkey: Mahir Cayan's Turkish Feople Liberation Party-Front (TPLP-F), Deniz Gezmış's 'Turkish People Liberation Army (TPLA), and

\footnotetext{
1 Üniversite Olaylan - İstankui Üniversitesi'nin Belgelere Dayanan Açlklaması, Istanbul: Servet Matbaası, 19:39, p. 31.

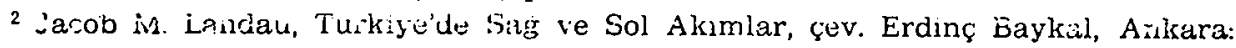
Turhan Kitabevi, 1979, p. 59.

${ }^{3}$ Sabri Sayarl, "Generationial' Changes in Terrorist Movements: The Turkish
} Case", The Rand Paper Sieries, 1985, p. 3. 
later İbrahim Kaypakkaya's Turkish Worker Peasant Liberation Army (TWPLA).

\section{B - BETWEEN RURAL AND URBAN TERRORISM}

The TPLA was founded both in Ankara and Istanbul in 1969. It was. supposed to have been led by Deniz Gezmiş. However the real leader and ideologist of the group was Hüseyin Inan. ${ }^{4}$ Despite his popularity among university students, Deniz Gezmiş was in general a militant, being far more interested in actions than in theories of revolutionary change. Sinan Cemgil's name was the second most important name in the TPLA.

The TPLA started systematic terrorist actions at the beginning of 1971. Firstly it kidnapped four American soldiers in İstanbul. This action helped to publicisize its name throughout Turkey. While a group of TPLA members continued urban terrorist actions in the big cities like Ankara and Istanbul, another group led by Sinan Cemgil met around MalatyaAkçadağ to begin rural guerilla operations. Their first aim was to destroy the Kürecik American Military Base. But they were discovered by a shepherd who informed the security forces about their existence in that area. In the ensuing battle between the group and the army units, some of the terrorists were killed while others were captured by the security forces. ${ }^{5}$ Later three important figures in the TPLA, Deniz Gezmis, Hüseyin İnan and Yusuf Aslan were arrested in İstanbul and Sivas. After their trial they received the death penalty and were executed in 1972 .

The TPLA was a Marxist-Leninist organization. In their opinion Turkey was occupied by The USA economically, culturally, and, to a certain extent, militarily. The country had been colonized, and was being controlled by the United States and its agents in Turkey. The electoral failure of the TPLA in the 1969 elections had made it clear that there would be no peaceful means of overthrowing the establishment. There was only one way: "armed conflict". Having believed in the idea that "the imperialist forces" could only be destroyed by means of revolutionary violence and that "the Marxist-Leninist revolution comes from the barrel of a gun", as Mao said, they envisaged "the great victory" as being very near. According to the strategy of the TPLA for revolution, the revolutionary movement would begin in the big cities and then would spread from the urban areas to the rural districts. Once the action of the TPLA

"Aydınlık, "Bilinmeyen Sol", 20 Mart 1979.

5 íclan Sayılgan, Türkiye'de Sol Hareketler, Istanbul: Otağ Yayınları. 197f, po. $544-45$. 
had proved that challenging the state was a viable proposition then popular widespread suppor:" was quickly forthcoming. There is no doubt that the TPLA member's were affected deeply by the success of Castro in Cuba and revolutionary struggle of Che Guevara in Bolivia. The ideologist of the group, Hiseyin Inan, tried to adopt the rural guerilla strategy formulated by Che Guevara for Turkey in his writings entitled: "The Way of the Turkish Zevolution". As would be expected, the basic conflict areas for the TPLA were the lural districts, in particular, the territory between Malatyi-Akçadağ and Adiyaman. Guided by the writings of Che Guevara, he leaders of the TPLA did not accept the formation of the national communist party (as defined by Orthodox Marxist-Leninist theory) a: an essential prerequisite for revolutionary change. As they perceived it the basic conditions for revolution existed in Turkey. Ideological corflict had to be kept in second place to the revolutionary process. The most immediate action to be taken was to organise small groups for armed conflict in chosen strategic areas. The second stage of the TPLA plan was to unify these small guerilla groups in order to form the national revolutionary army. ${ }^{6}$ This strategy, obviously, did not work and the JPIA was completely destroyed by the security forces in a short period of lime.

The TPLP-F, the secoijd terrorist organization in the first wave of terrorism, was established $k:$ Mahir Çayan, Ertuğrul Kürkçü, Münir Ramazan Aktolga and Yusuf Jijpeli. This group, too, was operating within the TLP in the beginnirg. Lfter the failure of the TLP in the 1965 elections it broke its ties with the party and joined Mihri Belli, a former member of the Turkish Corimunist Party and the leader of the National Democratic Revolutionary Movement. Then, in January 1971, they left Belli's group, publishing an open letter entitled "Open Letter to the Aydinlik Socialist Magazine"7, md formed the TPLP-F as an illegal organization. The Turkish People Lil:eration Party-Front militants started to carry out terrorist actions on 12th, Februrary, 1971, by robbing a bank in Ankara, and then killed the Is:aeli Consul General. At about the same time, Mahir Çayan, the leader o: the TPLP-F, was captured by the police. While on trial he managed ' $)$ escape from the military prison in İstanbul with some other terrorists. His final action, probably designed to secure the release of the TPLA.'s Ijeniz Gezmiş, Yusuf Aslan and Hüseyin Inan who at that time had been sentenced to death, involved the kidnapping of three foreign hostages in Northern Anatolia. I should emphasize that this operation and the place chosen to carry it out marked a very impor-

6 Aydinlik, "Bilinmeyen Sol", so Mart 1979.

'Mahir Çayan, Bütün Ya:slax. Istanbul: Devrimci Sol Yayınları, pp. 217-43. 
tant step in the development of Turkish terrorism. Çayan and his eight friends were killed in a shooting with the security forces during this incident in May $1972^{8}$.

Mahir Çayan was, and still is, the most important and influential firgure in terrorist movements, not only in terms of the strategy he tried to devise, but also in terms of the examples of extreme militancy he provided by his actions. It can be said that two main factors contributed to Çayan's prominence among the first and second generations of Turkish terrorists. Firstly, in contrast to Deniz Gezmiş, Çayan, within his own limitations, had a remarkable intellectual capacity. He tried to devise a new theory for Turkish revolution by combining traditional Orthodox Marxist-Leninist views with the ideas of Che Guevara, Castro and Debray. ${ }^{\circ}$ By writing several articles about revolutionary strategy he attempted to analyse the social, cultural and military conditions of Turkey from the socialist point of wiev. His ideas affected almost all revolutionary youth movements and terrorist organizations in Turkey. Secondly, "Çayan combined this intellectual orientation with a strong perchant for suicidal violence"10. During the late 1960 s and early 1970s in Turkey the worst insult for a leftist extremist was to be accused of being a pacifist. As Sayarı pointed out, by quating from "Ahmet Samim", a writer who has very strong links with leftist movements, Çayan's main fear was to appear to be a pacifist. "Çayan displayed a passion for weapons and a deep commitment to violent action. His death in a bloody hostage incident - in which he urged his fellow terrorists to fight until the bitter end despite the fact that they were surrounded by a large military contingent in a remote farm house- was typical of Çayan's quest for violent. tactics"1".

The TPLP-F's ideas and its strategy for revolution were improved and subsequently expounded by Mahir Çayan in his "Permanent Revolution I-II-III". Çayan based his strategy on an analysis of the present situation in Turkey. It was, in his opinion, a country occupied by the United States. Obviously this was not an open occupation. Rather, the country was being governed by a reactionary government consisting of the bureaucracy and the military, both controlled by America. "Real democracy" did not exist in Turkey. The Turkish experience of democracy was similar to that of Philipines. The only method available to rid them-

'Uğur Mumcu, Çıkmaz Sokak, Istanbul: Tokin Yayınları, pp. 5-10; 11-24.

- Atilla Yayla, Terror and Terrorism in Turkey: Fatsa Case (unpublisined doctorat-3 thesis), Ankara: 1986, chapter 4.

10 Sayar, op. cit., p. 6.

1 Sayar, op. cit., p. 6. 
selves of imperialist ciccujation and to establish real democracy, he believed, was through revolution. Within the Marxist-Leninist theory, revolution couldn't be realized through peaceful means such as parliamentary struggles, elections and so on. The only possible way for revolution was, as Lenin and Mau proved, to engage in revolutionary violence. In this context, Mao's ido:is, especially, were very important and the Maoist conception of the "p sople's war" took an extremly significant role in Çayanist strategy ${ }^{12}$.

According to this vew: revolution could take place through a long, diffucult war of the people against imperialist powers under the leadership of a strong elite gorup, i.e. ihe TPLP-F. However the people's war should not be expect to begin by $\mathrm{i}$ :salf and nor should the people be expected to join the war immediately. In addition the government was not as weak as some unrealistic revolut onary gorups supposed. Due to the relative power of the capitalist stat? and the temporary increase in standards of living in Turkey an "artifinal balance" had arisen between the people and the state during the $1 \subseteq 60 \mathrm{~s}^{13}$ Turkey had become industriaiized to a certain extent and the cor:munication and transportation systems had been improved. As a result the power of the state had begun to impinge on the furthermost corners if the country. The central state organization became much stronger than i: had been ten or twenty years ago. In these circumstances none of the revolutionariels could imagine that the people's war would start by itself. What was needed to bring it about was to express the "realities" to the people and to diclose the real face of the government. To do this, the basic devices available to the revolutionary forces were "the armed pre paganda" and "the vanguard war"

Armed Propaganda included rural guerilla war and psychological war against the governmer: $:$. These were to be conducted by the members of the revolutionary valiguard, namely the TPLP-F, to show that on no account was the state as strong as believed by the people. The successful campaign of violence by the revolutionary militants would prove the possibility of challenging; tha state. The second stage in the process was to be the people's war. Finilly the state would realize its incapacity for coping with the revolutionary forces alone and would call upon the US for assistance. Through Amrrican intervention Turkey was to be transiormed from being half-cocupied to fully-occupied. Naturally, the revolutionary forces, in this case, would have to seek help from the World

\footnotetext{
12 Yayla, op. cit., p. 238.

13 Cayan, op. cit., p. 378.

14 Ibid, p. 382.

15 Ibid., p. 389.
} 
Socialist Bloc, particularly the central power of the Socialist Bloc ${ }^{16}$. This last point, or, rather, expectation shows not only why the TPLP-F did its last action in Northeast Turkey, but also why the terrorist organizations that follwed the strategy of the TPLP-F paid special attention to the same area. Because beside its extreme suitability for guerilla warfare, it had direct sea and land access to the Soviet Union. In other words, it was the most convenient place to get help from "the central power of socialist bloc."16

So, the TPLP-F envisaged a civil war based on the pattern of Vietnam with the aim of creating a region liberated from the state which would be gradually widened by gradual inroads into the main land. Their plan was to divide Turkey into two parts: one to be supported by the socialist bloc and the other by American capitalism and "imperialism". No need to doubt the revolutionary aim was to win this civil war and save Turkey from imperialist occupation. As expected the Cuban revolution and the adventures of Che Guevara in Latin America in 1960s affected Çayan and his friends deeply and made them believe that they could succeed in Turkey. One of the leaders of the TPLP-F, Yusuf Küpeli, confirmed this by saying: "In that period of time we were considering Marighella, Lin Piao, Mao and Douglas Bravo as being on a par with Lenin..."i. "... There were some people who were imagining themselves in Vietnam or Cubs..."19.

The plan of the TPLP-F, like that of the TPLA, did not work. Mahir Çayan and eight other guerillas were killed in an armed battle with the security forces. The other members of the TPLP-F were also captured and jailed after trial. By the year 1973, the TPLP-F had become a dead organization. However this was not end. After the general amnesty in 1974, more than a dozen terrorist organizations each of which claimed to be the true followers of the TPLP-F appeared all over Turkey.

The third terrorist organization between 1969-73 was the Turkish Worker Peasant Liberation Army (TWPLA). The leader of the TWPLA, İbrahim Kaypakkaya, desired to, immediately, start the guerilla war in the rural areas. For him, the masses were waiting for the armed struggle not for speech or publishing magazines ${ }^{19}$. It should be made clear that, in comparison with' the other terrorist organizations of the same period the TWPLA was the more radical and separatist. Its strategy for revolution

is Ibid., p. 324.

${ }_{17}$ Mumcu, op. cit., p. 76.

18 Ibid., p. 78.

is Ibrahim Kaypakkaya, Bütün Yazılar I, Istanbul: Tufan Yayınları, 1976, p. 78. 
was based on Kurdism, a med struggle and Che Guevara's "focoism". Kaypakkaya thought that the necessary prerequisities existed in East and South Anatolia to conduct guerilla warfare. It was quite easy in these districts to set up "liberatec red areas" and to defend them against the state. The territory was ertirely suitable to long-term guerilla warfare and the people living in Eistern Anatolia could form the basis of the revolutionary guerilla movement's army. In other words, "the objective conditions" of the revoluticn existed ${ }^{20}$. The absence of the subjective conditions, i.e. party and rel army, would not matter in these circumstances. Kaypakkaya's organization was to constitute the nucleus of the red army. While it struggled against the imperialism the people would create the party and eventu:lly the red army. ${ }^{21}$.

According to the T'WI'LA's strategy, first the local red political governments were to be set up with armed struggle in strategically important places within Southerast Turkey. The second step was the unification of the local armed forces to create a national united front, a regular army.Then all the large citics in Turkey would be beseiged by this army. Meanwhile in these cities the urban guerillas would organise riots, conquer the security forces and make the job of the red army easier.

Obsiously, within this frimework, Kaypakkaya didn't see revolution's conclusion as being far off. in order to apply his idcas in real life, Kaypakkaya started to carry out rural guerilla warfare in Southeast Anatolia after the military intervan:jon of 12th March 1971. Two years later, in January 1973, the securily forces found him and after an armed battle captured him in Tunceli, the main area of his activity. While he was being questioned on 17th May 19:3, he, according to the police, committed suicide. According to his frit:1lds, however, he was tortured to death by the police ${ }^{22}$.

Thus, by the time the 1.973 general elections the TPLA the TPLP-F, and the TWPLA had been (liminated by the security forces, prominent figures in these organizatior:s had been either killed, or executed, and other members had been jailed. Unfortunately this was not the end of lerrorism in Turkey. In other words, it was only the end of the first wave of terrorism. Soon, in 1-2 yitars time, many new terrorist organizations would appear and present themselves as followers of the TPLA, the TPLP-F or the TWPLA.

\footnotetext{
20 Ibid, pp. 308-310.

21 Saylgan, op. cit., p. 564.

22 Ibid., p. 562 .
} 


\section{THE SECOND WAVE OF TERRORISM: TERROR OR CIVIL WAR}

The second wave of terrorism in Turkey, taking place between 19751980, differed from the first in three respects: ideological diversity, the size of terrorist organizations and the calibre of the terrorists.

In contrast with the three organizations of 1968-73, almost twenty terrorist organizations of both left and right wing persuasions operated from 1975 to 1980 . Consequently the number of people who involved terrorist activity increased dramatically from several dozens to almost thirty thousand. Simultaneously, the increasing militancy of the new terrorist organizations spread from the cities to the towns. As expected, the larger the terrorist organization the less qualified its militants and the more brutal their actions. Thus Turkey underwent a unique period of terror forcing the horror struck majority to choose between an inoperative democracy and the unity of the country.

Some twenty radical left wing organizations engaged in direct terrorist activity. All these considered themselves the true followers of the TPIAA, the TPLP-F and the TWPLA. Ogunzhan Müftüoğlu, formerly a member of the TPLP-F, who was later freed during general amnesty of 1974, set up the most popular organization, the Revolutionary Path (RP) with the aid of his friends. The RP was to split into two groups in 1978 and the splinter group, led by Paşa Güven, also a former member of the Çayanist group, called itself the Revolutionary Left (RL).

Çayan's wife Gülten, who moved to Paris after the death of her husband, founded the Marxist-Leninist Armed Propaganda Union (MLAPU) which was to beccme one of the most bloody terrorist groups prior to 1980 .

The organizations mentioned above were, by and large, ideological; ethnic separatism did not take an important place in their policies. But some other organizations such as the Kurdistan's Worker's Party (KWPPKK), the Kurdistan National Liberation (KNL-KUK) were basically ethnic-separatist movements. It could be said that in the second wave of Turkish terrorism the emergence of such separatist groups as these posed possibly the most serious threat to Turkish unity. The fact that some ethnic separatist organizations have been continuing to carry out terrorist activity in southeast of Turkey would seem to confirm this.

Many left wing terrorist organizations in the second wave were led by well-known former militants, who had been freed in the 1974 general amnesty. They retained the views of the former organizations and did not or could not produce new ideas. In addition, although they considered 
themselves Marxist-Lerinisit, they did not share the same convictions about M-L and its revolutionary strategy and defended Enver Hocaism as well as Leninism, Stalinism and Maoism. The ideas of Latin American revolutionaries such as Cie Guevara, Castro, Marighella seemed to be less important to their wey of seeing revolutionary conflict, and they preferred to concentrate their so-called intellectual activities on the interpretation of Orthodox $\mathrm{M}-\mathrm{L}$.

The largest organization which grew out of the TPLP-F, the Revolutionary Path, focussed its activities in Northeast Anatolia, particularly in Futsa as had its predecessor. The RP wanted to establish a prototype organization for the future; in their own words, "to establih a rival authority in opposition to central government power". The capture of the local government office cif Mayor facilitated their activities, in turn broadening their range of influence. The prototype political authority set up by the RP establisleed itself administratively through local governrnent. Those who ventures to oppose or: challenge the totalitarian authority of the RP in locia! government were immediately neutralized through intimidation, coevion or physically liquidation. Until central government initiated "cperation pinpoint" in the area which was carried out by the police and arm! the RP ruled the local area unchallenged by organizing local judiciary bodies to prosecute those who clared oppose its power...

Unlike their predecessir's the left wing terror organizations of the second wave intensified their activity in the large cities. Not only did they use violence against officials and security forces, but also against their own rival organizations of the left as well as against right wing extremists. Not surprisinglir, from time to time, terrorists were violent amongst themselves, againsit their fellow militants in the name of organizational discipline and icieological purity.

The Idealist Youth Mcrement (IYM) appeared to be the main right wing terrorist organization during the period leading up to 1980 . Despite its appearance as a separale-independent organization, it was in fact, a front organization for thu: extreme-right wing National Action Party (NAP) and it was controlled by the leader of the party, Alpaslan Türkeş. Till 1977 the IYM was considered to be a reactionary movement against the increasing number of: li:ft wing groups and the threat of communism. Its stated aim was to assist the state against the communist threat. After staying a relatively small movement until 1977, the IYM started to grow rapidly when the National Action Party became a partner of the coalition government led by Silejman Demirel. In these circumstances it was transformed from being an !noffical political instrument to an organizatıon 
that slowly began to dominate the state. During the Republican People's Party years of office under the leadersihp of Bülent Ecevit, the IYM lost its influential position within state affairs, but started to gain the support of the many middle-class people who were afraid of the extreme left wing movements which also used some state facilities in 1978-79.

The ideological appearance of the IYM was not conveyed very clearly. It could be said that in fact it did not posess a clear and complex ideology. Alpaslan Türkeş tried to devise an eclectic ideological stance both for the NAP and the IYM. The so-called doctrine he tried to expound consisted of aifterent ideas borrowed from diverse ideologies including socialism as well as fascism. He called his doctrine "9 lights". In general, the ideology of IYM was based upon Turkish nationalism, collectivism, anti-communism and admiration of the state. At that time Islam did not play a significant role in their way of thinking. But in 1980 their world view began to change and Islam became the predominant factor in the ideology of IYM. In the same year their most popular slogan was: "Islam is victorius even our blood is shed". So their aim changed from assistance to the state in its struggle against communism to fighting to establish "the holy order of the world' (nizam-1 alem). In accordance with this change, instead of "glights", they tended to talk about "the idea of holy world order" (nizam-1 alem ülküsü), and in their publications they were projected as the defenders of holy Islamic ideas.

- The Raiders Association (RA) was born as the second right wing terrorist organization in 1980 . Being the youth organization of the National Salvation Party (NSP) it accepted Islam as a total ideology and followed the idea of Islamic revolution. It is not unfair to say that the Islamic revolution of Iran that tookplace in 1979 deeply affected the RA. This view is strengthened by the fact of its late apperance despite the existence of the NSP as a relatively strong political party from 1973 to 1980.

As has already been said the RA interpreted Islam as a universal ideology and rejected all "Western ideas" including nationalism and democracy. What it wanted was a pure Islamic regime far removed from all tine "wickedness" of modern culture. The ideologists of this fundamentalist movement saw left wing ideas as being closer to their own than those of IYM. They opposed the current political regime and in this sense they were also revolutionary. Since it has only been existence for a short while, the RA did not develop particular pattern of violence. However, not surprisingly, despite being a right wing group it generally chashed with IYM militants and in some areas co-operated with left wing organizations against the IYM. 


\section{THE GENERAL FROILE OF TURKISH TERRORISTS}

Not surprisingly in the first wave of terrorism in Turkey virtually all of the terrorists were, $r$ Turkish standards, well educated university students. This is not strange when we remember the similarities with Western countries. In 1968, all student movements in the West were led by the students affected by the ideas of the new left wing thinkers, especially $H$. Marcuse. In contrast, Marcuse, as was pointed out, did not affect Turkish students, be ause, probably, Turkey was not a developed consuption society. Inste:ad of Marcuse, Turkish students were influenced by Lenin, Mao and partly by Che Guevara, Castro and Debray... Thus, Turkish students, differing from their contemporary students in the West whose main activities were to organise rallies and mass demonstrations, chose to set up srnall armed groups to fight against the state. So, all levels of the terrorisi, or anizations, especially the ranks of leadership, were filled by the students...

Mahir Çayan, Hüseyin Jıan and İbrahim Kaypakkaya were university students when they esteblis hed and led their organizations. And so were their closest colleagues, suct as Yusuf Küpeli, Sinan Cemigil, Yusuf Aslaı and so on. They used thu: universities, particularly the Middle East Teuhnical Universily arid ne Faculty of Political Science of Ankara University, as their headqu inters, Few officers or military students held ranks in the terrorist orgarizations like Orhan Savaşçı, Çayan's brother in law, and Satfet Alp. 'Th: terrorists in the first wave who were later to be known as the 1947 generation were in general in their $20 \mathrm{~s}$. On the whole they came from midile or upper class families. For some of them their families played a siglificant role in their political orientation like Sinan Cemgil, whose father Adnan Cemgil was a well-known name of the socialist movement. Others were greatly affected by the left wing publications that boomed after the 1961 constitution.

In the second wave of torrorism the basic characteristics of the terrorists changed in several ruspects. The leaders of the organizations were no longer students. Either they had finished or they left the university after wastirig their time in "Wo unnecessary "capitalist" education process. The most significant people! in the new organizations were in general former members of the fir;: three groups of the first wave. Despite the appearance of several new prominent names within the terrorist organizations of the second wave, forner figures maintained their leading positions. The lower echelons of the terrorist organizitions generally included students, officials, workers and unemployed people. According to a survey conducted on 820 terrorists from both left and right organizations, $35 \%$ 
of them was student, $21 \%$ workers, $14 \%$ officials and $11 \%$ unemployed, persons ${ }^{23}$.

Turkish terrorists were by and large, between the ages of 18 and 26. In the survey mentioned above $75 \%$ of terrorists was found to be in the 18-26 age group ${ }^{24}$. As expected the terrorist organizations included very few female: $2.8 \%$ in the right wing, $9.2 \%$ in the left wing. The great majority of militants were single and only 20 percent was married $^{25}$. Turkish terrorists came from middle class families, 26 per cent of the terrorists' fathers was workers, $23 \%$ farmers and $15 \%$ small entrepreneurs ${ }^{26}$. Despite the fact that they were born in small villages or towns, they spent most of their life in the big cities, particularly in Ankara, Istanbul, and İmir. Their parents' level of education was relatively low. When we compare the basic characteristics of leading militants with those of ordinary terrorists, the former are seen to have come from families of a relatively higher level of education. As expected they were better educated, and so able to organise their fellowers and io produce or interprec the ideology and strategy.

\section{CONCLUSION : THE FUTURE OF TERROR IN TURKEY}

After the military coup in 1980 and the' establishment of military rule, all terrorist organizations were destroyed in a very short period of time and thousands of militants were imprisoned after being tryed. The result seemed to be a great success in terms of coping with terrorism. In fact few people expected the military rule to be so successful against terrorism because some terrorist organizations included thousands of militants, and seemed to be as strong as a local army in some areas. For example, the Revolutionary Path believed that at least fifteen thousand reopie would fight against the police and army if they threatened RP's government of Fatsa. But this expectation did not come true and only a few militants faced the security forces during the military operation to purge the area of terrorist. This proved that despite their immense propaganda terrorist organization couldn't make the people believe in their way of thinking and fight against policemen and soldiers. This is the main reason why the terrorist organizations could be purged so easily.

$\overline{{ }^{23} \text { Hüseyin Ağca }}$ - Güner Omay, "Area Research Study About the Persons Arrested Because of Participation in Anarchitic Actions", (paper presented to the international symposium of the 'rehabilitation of terrorist') (stanbul, 1985, p. 20.

24 Ibid., p. 3.

25 Ibid., p. 20.

28 Ibid., p. 24. 
However it does not man that there will be no new waves of terror in Turkey in the future. Anctually Turkey is now coping with the third wave of terrorism. It seem:i to me that in years to come Turkey will be faced with two main strams of terrorism: idcological/revolutionary terrorism and seperatist terrorism.

Militants of the left wing terrorist organizations who escaped from prison or who finished their imprisonment have been carrying out some terrorist activities in the big cities. They are likely to recruit new militants from the universitie: since totalitarian tendencies that stimulates the use of violent tactics ase still popular among the university students. But it seems that on account will they be able find as many militants as they recruited before 19:30. Jeither do they have much chance of achieving the support of the people $x$ ho suffered severely from terrorism. It can be said that the left wing violence organizations are likely to remain extremist, fanatical group:s who will probably carry out more orutal but less wide-spread terrorist iutivities...

Separatist terrorist organizations, particularly the KWP will be continuing their terrorist activities in Southeast Anatolia for a relatively prolonged period. The KWP is an international terrorist organization which is posing a complex ind difficult situation for Turkey. International cooperation is needed to $s \% p$ the KWP carrying out terrorist activities and there is no sign that Sy ia, where the KWP is based, has any intention of cutting off its support; tis the KWP. However, the new policy of the Soviet Union towards inte:national relations and some changes in relations between Syria and the rest of the Islamic world may affect Syria to a certain extent and mals it reconsider its support of the main separatist terrorist organization E.WP.

So, terrorism in Turs:y has not ended and will not end for the foreseeable future. But there is little possibility that terrorism will threaten the democratic regsime and unity of Turkey as it did before the 1980 military coup. The ggeatest hope for Turkey in its struggle with terrorism is this: Turkish people, knowing what it is, hate terrorism. Unless the terrorist movernents find a way of convincing the people that the way of terrorists is best they have no chance to change the political regime of Turkey nor to cause division in Turkey. 